\title{
BOSANSKOHERCEGOVAČKA KNJIŽNA KULTURA I PUT SVILE: OD POČETAKA INSTITUCIONALIZACIJE DO SAVREMENIH DIGITALNIH PRAKSI BAŠTINSKIH USTANOVA
}

\begin{abstract}
Sažetak
Bosanskohercegovačke ustanove baštine - prije svega arhivi, biblioteke i muzeji, pohranjuju i brojne vrijedne rukopisne kodekse nastale u zemljama Bliskog i Srednjeg Istoka, među kojima su i rukopisi nastali počev od 12. st. pa nadalje. Rukopisi arapskog, turskog i perzijskog porijekla, naknadno obogaćeni prijepisima ili autografima autora bosanskog porijekla, i danas su jedni od najvrednijih fondova u bosanskohercegovačkim baštinskim ustanovama. Rukopisi, kao i ostali elementi knjižne kulture zasigurno su stizali u Bosnu i posredstvom Puta svile. Rad rekonstruira utjecaje brojnih bliskoistočnih i srednjoistočnih, a posredno i dalekoistočnih kultura na prošlost te na sadašnjost bosanskohercegovačke knjižne kulture, odnosno vezu s Putem svile kao sa svjetski prepoznatljivim kulturnim i komunikacijskim čvorištem.
\end{abstract}

Ključne riječi: knjižna kultura, rukopisni kodeksi, Bosna i Hercegovina, Put svile, baštinske ustanove, digitalizacija

Bosanskohercegovačka knjižna kultura jedna je od onih s dugom, raznolikom, na mahove prelomljenom, ispresijecanom, usložnjenom, ali nadasve specifičnom tradicijom, što su pretpostavke koje će je i danas u Evropi kontekstualizirati kao jednu od najstarijih potvrđenih državnih pismenosti, počev od najstarije ćirilične povelje pisane narodnim jezikom - Povelje Kulina-bana iz 1189. - ali, vjeruje se, i još starijih nepreživjelih dokumenata, ne razmatrajući u ovom kontekstu još stariju epigrafsku, ali i ovosvjetovnu, čisto pragmatičnu grčko-rimsku pismenost - poput one na

Filozofski fakultet, Zmaja od Bosne 1 \& Franje Račkog, Sarajevo 71000

lejla.kodric-zaimovic@ff.unsa.ba;

lejla.kodric.zaimovic@gmail.com 
novcima i predmetima za svakodnevnu upotrebu - koja u svojim izvjesnim formama opstaje i u vremenu bosanskohercegovačke srednjovjekovne pismenosti.

Na toj ranijoj tradiciji Osmanlije u Bosni i Humu u 15. st. zatiču krajnje razvijenu pismenost, ponešto glagoljsku, ali prije svega ćiriličnu, i to, što posebno valja naglasiti, bosanskoćiriličnu, pismenost koja je mahom obitavala u crkvenim organizacijama, dvorovima, kancelarijama oblasnih gospodara, moguće je u svojim rudimentarnim, protoformama i među trgovcima i zanatlijama, ali ipak najčešće potvrđena rukom dijaka - profesionalnog prepisivača - čije tragove pratimo još od 12. st., dok veliki broj imena dijaka na stećcima i u rukopisnim knjigama upućuje da je postojala potreba za vještinom pisanja.

I kako u lucidnom, faktografski utemeljenom, ali i gotovo poetski ispisanom uvodniku zbornika Pisana riječ u Bosni i Hercegovini: od najstarijih vremena do 1918. godine, unutar sad već gotovo kanonski važne biblioteke te izdavačkog projekta Kulturno naslijeđe Bosne i Hercegovine iz druge polovine 20. st., zapaža uvodničar Džemal Čelić:

Na poprištu sukobljavanja, uzajamnih potiranja, ali i neminovnih mirenja, preplitanja i prožimanja divergentnih kultura i civilizacija nijedan domen stvaralaštva nije mogao ostati jednoznačan. Za narode koji su u prošlosti živjeli, ili danas žive, na teritoriji Bosne i Hercegovine, ovdje na granici grčko-helenističkih i etrursko-rimskih zračenja, na prostoru gdje se Mediteran susreće s utjecajima iz centralne Europe, na limesu Istočnog i Zapadnog rimskog carstva, na sredokrači zapadno-europskih i bliskoistočnih susreta, na marginama najvećih civilizacija koje pozna historija, ni pismenost, kao ni drugi oblici stvaralaštva, nije mogla biti jednoznačna. (1982: 5)

Jednako tako nastavljajući, Čelić konstatira da je:

Od samog početka tog srednjovjekovnog društvenopolitičkog žića, ova zemlja opet u znaku preplitanja suprotnosti Istoka i Zapada. Prepliću se utjecaji i shvatanja bizantijska i zapadnoeuropska, ortodoksna i rimokatolička, grčko pismo prema latinici, pa ćirilica prema 
glagoljici, pa umjetnost bizantijskog kruga prema preromanici, romanici i gotici. U sažimanju i kreativnom (aktivnom) odnosu prema tim suprotnostima afirmiše se bosanska državnost i samostalnost u politici, sasvim specifična bosanska crkva u religiji, bosanska ćirilica i bosanska glagoljica u pismenosti, bosanska minijatura i iluminacija u opremi knjige, a posebno umjetnost stećaka koja na likovnim predstavama, u simbolima i u epigrafici objedinjuje najveći broj stvaralačkih specifičnosti. Upravo u domeni pisma i knjige, reljefnije nego u bilo kojem drugom mediju, raspoznaje se prisustvo pojedinih utjecajnih sfera, ali i originalni stvaralački doprinos ljudi ove zemlje. (1982: 8-9)

Pored crkvenoreligijske (rukopisne), potom epigrafske / lapidarne pismenosti, kao samostalna država srednjovjekovna Bosna imala je razvijenu i svoju administrativno-pravnu pismenost, mahom na bosančici, u koju se ubrajaju povelje, ugovori, testamenti, darovnice, službena i privatna pisma koja su pisali vladari i feudalci, od kojih su neki imali i vlastite skriptorije:

Nije beznačajna činjenica što je utvrđeno da su vlastite skriptorije imali gotovo svi značajniji feudalci, kao što su Kosače, Hrvatinići, Sankovići, Pavlovići i dr., jer su se u tim kancelarijama mogla pisati i druga djela, a ne samo administrativno-pravni spisi; tako je, npr. i Čajničko evanđelje napisano u jednoj takvoj kancelariji (skriptoriju). Ipak, većina ovih dokumenata nije se sačuvala u Bosni, nego se nalaze po arhivima Dubrovnika, Budimpešte i Beča, što je sasvim adekvatno sudbini i drugih bosanskih spomenika. (Kuna 1982: 61)

Do kraja 15. st., postepeno, oblici bosanskohercegovačke srednjovjekovne pismenosti utišavaju se, ali zasigurno ne prestaju u cijelosti, posebno ne oni ćirilični, koji i dalje, svaki na svoj način, nastavljaju istrajavati svojim osobenostima unutar tri vjersko-konfesionalna toka: pravoslavnom, katoličkom i muslimanskom, dok su najvredniji bosanskohercegovački srednjovjekovni arhivi i kodeksi, izuzev Čajničkog evanđelja koje je i danas u Bosni i Hercegovini, odneseni iz zemlje ili uništeni, a preživjeli 
ostaci važne srednjovjekovne bosanske pismenosti danas se pronalaze u arhivima i bibliotekama diljem svijeta: Rimu, Veneciji, Bolonji, Istanbulu, St. Petersburgu, ali i u zemljama bivše zajedničke države.

Tako je bosančica, poznata i kao begovica ili „žensko pismo“, za muslimansko stanovništvo isključivo svjetovno pismo, od 15. st. koriste ga lokalne, osmanske vlasti za korespondenciju s nemuslimanskim okolnim stanovništvom, posebno s Dubrovnikom, a ćirilična kancelarija nalazi se i u Istanbulu. Bosančica traje gotovo do 20. st., u reliktima i kasnije, čak i danas, uz prihvatanje Vukove ćirilice te latinice. Kod pravoslavaca ćirilica je i dalje vezana uz liturgiju, odnosno rukopisnu crkvenu knjigu, dok treći ćirilični tok nastavlja trajati među franjevcima te u franjevačkim samostanima, s reprezentativnim primjerom prve knjige štampane bosančicom na narodnom, bosanskom jeziku Nauk krstjanski Matije Divkovića iz 1611. godine. U multikulturalnoj teokratskoj osmanskoj državi slika Bosne mijenja se i dolaskom Jevreja Sefarda u 16. st., a koji, mahom opismenjeni u svojem pismu i jeziku, obogaćuju domaću knjižnu kulturu, donoseći pritom i svoj čuveni srednjovjekovni iluminirani kodeks, Sarajevsku hagadu, kao, moguće je, jednu od danas svjetski vrednijih hagada.

Uz razvijenu pismenosti, srednjovjekovna Bosna, barem prema dosadašnjim istraživanjima, uspostavila je sistem kancelarija, skriptorije, crkvene riznice i, uopće, zavidnu knjižnu kulturu, ali, ipak, ovdje prije govorimo o kolekcijama spisa, knjiga i predmeta, dostupnim ograničenom broju rijetko pismenih ljudi, nego o bibliotekama kao samostalnim ustanovama ili o kao tzv. bibliotekama u sastavu, što su tekovine koje u Bosnu stižu s osmanskom kulturom, kao jedan od njezinih direktnih doprinosa razvoju bosanskohercegovačke knjižne kulture, dok „,vrijeme bosanske samostalnosti, pa dobrim dijelom i osmanske uprave u Bosni i Hercegovini, barem što se tiče biblioteka, ostaje otvoreno za nova istraživanja“ (Hadžiosmanović 1982: 285). ${ }^{1}$

Jasno je, osmansko vrijeme u Bosni moglo je institucionalizirati te podupirati samo biblioteke na vjersko-konfesionalnoj osnovi, nasljeđuju-

1 U novije vrijeme istraživanjima Lamije Hadžiosmanović pridružuju se i savremeni autori: Senad Čeliković u knjizi Islamske biblioteke u Bosni i Hercegovini: 1878-2010 iz 2014. te Osman Lavić u odbranjenom magistarskom radu Biblioteke u Bosni za vrijeme osmanske uprave iz 2013., popunjavajući raniju prazninu bavljenja bosanskohercegovačkim bibliotekama u osmanskom periodu. 
ći, odnosno zatičući jednako takvu knjižnu kulturu u Bosni, dok se od austrougarskog perioda u Bosni pronalaze moderne državne biblioteke, ali i ostale baštinske ustanove, s Bibliotekom Zemaljskog muzeja kao prvom bibliotekom državnog tipa u Bosni i Hercegovini iz 1888., a koja će sve do osnivanja Nacionalne i univerzitetske biblioteke Bosne i Hercegovine, tada Narodne biblioteke Bosne i Hercegovine iz 1945. godine, i stvarno i suštinski nositi bibliotečki sistem zemlje, između ostalog i kroz instituciju tzv. obaveznog primjerka.

Već izdiferencirana, prepoznatljiva srednjovjekovna bosanska knjižna kultura stubokom se mijenja uspostavom osmanske uprave u Bosni, postepeno donoseći novi religijski svjetonazor, novo, arapsko pismo, bilo u svojem izvornom obliku, bilo u svojoj kasnijoj inačici prilagođenoj glasovnom sklopu bosanskog jezika, dakle, u vidu tzv. arebice, kao i arapski, turski i perzijski jezik, svaki s jasno definiranom namjenom te praksom u Bosni, bilo kao jezik nauke, jezik administracije, ili, pak, kao jezik lijepe riječi ili književnosti. Prelazak na islam, novostečene feudalne privilegije u tek uspostavljenom osmanskom upravnom sistemu u Bosni, u samom početku odredit će pravce budućeg obrazovanja bosanskih muslimana u velikim islamskim centrima Bliskog i Srednjeg Istoka, dok se vremenom počinje odigravati i suprotan proces, proces doprinosa ovdašnjih ljudi islamskoj knjižnoj kulturi, nauci i umjetnosti uopće, spomenuvši ovdje, recimo, tek Hasana Kafiju Pruščaka, Matrakčiju, Osmana Nakaša ili Šejha Juju.

Bosna se, dakle, dolaskom Osmanlija, postepeno uklapa u također već krajnje jasnu, razvijenu i izdiferenciranu knjižnu kulturu, zasnovanu na instituciji vakufa, grada, urbanizma, školstva, biblioteka, naprednih tehnologija proizvodnje papira, uvezivanja, iluminiranja te koričenja rukopisne knjige. Sve nabrojane civilizacijske tekovine, uz razmjenu ideja, vjera, jezika i dobara zasigurno su tekle i Putem svile, dopirući posredstvom osmanske kulture i u Bosnu kao najzapadniju provinciju Osmanskog carstva. I kako lucidno zapaža autor P. Frankopan:

Putovi svile nemaju tačno određen početak niti završetak, zato što to uopće i nisu pravi putovi. Riječ je o spletu mreža koje su omogućavale robi, ljudima i idejama, ali i bolestima i nasilju, da struje $s$ istoka prema zapadu te sa zapada prema istoku; od pacifičkih obala 
Kine i Rusije, pa sve do atlantskih obala Europe i Afrike te također od Skandinavije na sjeveru do Indijskog oceana na jugu. O Putovima svile možemo razmišljati čak i kao o središnjem živčanom sustavu svijeta koji povezuje sve organe u tijelu ili možda kao o venama i arterijama koje zajedno sa srcem dovode i odvode kisik i ugljični dioksid. (2018: 10)

Utabanim putevima velikih civilizacija i njihovih razvijenih gradova, i u Bosnu kao Zapadu najistureniji krak Osmanskog carstva, stižu ovim podnebljima ranije nepoznate, strane tekovine, poput institucije vakufa. Razumijevanje doprinosa islamske civilizacije bosanskohercegovačkoj knjižnoj kulturi nije moguće bez razumijevanja uloge i značaja institucije vakufa u islamskoj kulturi uopće:

Vakuf (zaklada) ili vakufljenje (zakladništvo) odlika je ne samo islamske, već i drugih, starijih civilizacija, ali su u osmanskoj državi i društvu vakufi nositelji cjelokupnog kulturnog, socijalnog, prosvjetnog i religijskog života Carevine. [...] Ufakufljavanje se kroz historiju vršilo prvenstveno za vjerske ciljeve, za podizanje i izdržavanje džamija, za podizanje i izdržavanje medresa, mekteba i drugih vjerskih i kulturnih ustanova; zatim u dobrotvorne svrhe, za održavanje imareta u kojima su siromašni i putnici besplatno dobivali hranu, bolnica, hanova te za opće svrhe, naprimjer za izgradnju i održavanje hamama, vodovoda, česmi, mostova, puteva i dr. (Dizdar 2010: 16)

Nekolicina gradova u Bosni i Hercegovini svoje ime dobila je upravo po vakufima: Gornji Vakuf, Donji Vakuf, Varcar Vakuf, Skender Vakuf (Dizdar 2010: 16), a što svjedoči snažnu ukorijenjenost institucije vakufa u osmansko, pa tako i u bosanskohercegovačko društvo. Upravo posredstvom institucije vakufa u Bosni se od druge polovine 15. st. odigrava snažna urbanizacija, uspostava sistema osnovnog i višeg školskog obrazovanja, prodora pismenosti, što za posljedicu ima širenje čitateljskog auditorija te, na koncu nastanka biblioteka u svojem institucionalnom smislu, što je za Bosnu novina u odnosu na ranije, izolirane, sporadične kolekcije knjiga. 
lako je Bosna i Hercegovina bila u okviru feudalnog carstva, karakteristično je i značajno da se kulturno-prosvjetni, naučni, književni i umjetnički život ne svodi na 'crkvene' krugove i feudalnu elitu, nego ima znatno popularniji, demokratskiji karakter. Naime, zahvaljujući nastanku i razvoju relativno većeg broja gradova i gradskih naselja i strukturi stanovništva i djelatnosti u njima, obrazovanje i kultura su živo prožimali široki krug stanovnika gradova - trgovaca, zanatlija, službenika, vojnika, sveštenika, učitelja i drugih. O tome svjedoče brojni podaci o prepisivačima knjiga i kaligrafima, koje nalazimo u bilješkama u rukopisima, u nekim vakufnamama; o tome također svjedoči i broj privatnih biblioteka koje se javljaju već u drugoj polovini 15. st. Kasnije, jedva da je bilo ijedne iole uglednije i obrazovanije porodice koja nije imala bar skromnu biblioteku, a u većini kuća se nalazila bar po koja knjiga. Ostaci privatnih biblioteka mogu se i danas naći po Bosni i Hercegovini, a mnoge od njih su otkupljene za naše i strane fondove. Posebno su, u vezi s ovim, pored sidžila, zanimljive neke vakufname (darovnice) u kojima se navode spiskovi knjiga koje njihov vlasnik zavješta kakvoj kulturnoj ili prosvjetnoj ustanovi. Na taj način nastale su brojne biblioteke, od kojih neke i danas žive [...] iz sidžila - sudskih zapisnika, iz onih njegovih mjesta koja se odnose na zaostavštine, može se sasvim lijepo vidjeti i broj knjiga - rukopisa koje su posjedovali pojedini vlasnici. (Grozdanić 1982: 85)

O svemu ovom saznajemo i iz Ljetopisa najvažnijeg sarajevskog hroničara osmanskog vremena Mula Mustafe Bašeskije², a koji navodi i imena nekolicine bibliotekara, kao i vlasnika privatnih biblioteka, uz kaligrafe, mualime (učitelje), muderise (profesore) te mudželite (knjigovesce). Zna se da su dvije sarajevske ulice, koje postoje i danas - Veliki i Mali Mudželiti - bile rezervirane samo za knjigovesce. (Kreševljaković 1958: 234-240)

Usto, ugledni bosanskohercegovački orijentalist M. Mujezinović u Bosni za vrijeme osmanske uprave evidentirao je čak 150 privatnih biblioteka, odabirući kao donju granicu ili kriterij postojanja privatne biblioteke najmanje deset knjiga, što je sasvim razumljivo te opravdano s obzirom na

Više o ovome i o sličnim primjerima usp. Bašeskija, Mula Mustafa. Ljetopis (1746-1804). Prijevod s turskog, uvod i komentar M. Mujezinović, 1968. 
to da se radi o rukopisima nemale vrijednosti. Isti autor, baveći se bosanskohercegovačkom epigrafikom osmanskog perioda, zabilježio je preko 5000 osmanskih epigrafskih spomenika u Bosni, a o doprinosu islamske civilizacije razvoju bosanskohercegovačke knjižne kulture svjedoči i preko 500 zabilježenih domaćih autora koji su stvarali književne i druge tekstove na arapskom, turskom i perzijskom jeziku. ${ }^{3}$

Uz epigrafiku nastajalu u kamenu, drvetu, na javnim objektima, mostovima, karavan-sarajima i drugdje, osmanska civilizacija u Bosni, pored književnosti, umjetnosti i obrazovanja, ostavila je golemi trag u obilnoj administraciji (danas reprezentativnoj građi odabranih bosanskohercegovačkih biblioteka i arhiva), i to u vidu vakufnama, fermana, berata, bujuruIdija, sidžila, deftera i dr., od kojih posebno vakufname, uz čisto pragmatski, nerijetko njeguju i literarni karakter te su reprezentativni dokumenti bosanskohercegovačke osmanske prošlosti.

Očito je, upravo s islamsko-osmanskom civilizacijom u Bosni i Hercegovini uspostavljaju se temelji, prototipovi kasnijih baštinskih ustanova povezanih s vjerskim zajednicama u Bosni i Hercegovini i danas, mahom posredstvom vakufa te zahvaljujući njemu, s principom javnosti za sve koji poznaju orijentalne jezike, zbog specifičnosti sakupljane građe, što su pojave posve strane bosanskom srednjovjekovlju, ali i pojave koje svojom „modernošću“ korespondiraju postepenom otvaranju biblioteke ka široj javnosti u ondašnjoj Evropi iz doba humanizma i renesanse.

Vakufske biblioteke osnivaju državnici kao dio svojeg namjesničkog programa, uz medrese, mektebe, tekije, ali, što posebno valja naglasiti, i kao samostalne biblioteke u zasebnim, namjenski građenim prostorima, što je pojava krajnje reprezentativna imajući u vidu vrijeme o kojem govorimo. Tako je, recimo, Gazi Husrev-begova biblioteka u Sarajevu, kao vakuf istaknutog sarajevskog i bosanskog namjesnika i vakifa Gazi Husrev-bega, osnovana 1537. godine, trajući sve do danas kao jedna od najbogatijih orijentalnih biblioteka Balkana, pa i dalje. Uz medrese (po statusu i programu i danas odgovaraju klasičnim gimnazijama, a nekada su bile u rangu viših i visokih škola, čak i novoosnovanih evropskih univerziteta), „kojih je za turskog vremena u ovim krajevima bilo preko 100“ (Kaleši 1961: 280),

3 Usp. cjelokupan naučno-istraživački opus M. Mujezinovića, a posebno Islamska epigrafika Bosne i Hercegovine (knj. I, knj. II, knj. III). 
različitog ranga i statusa, obavezno se pojavljuju i odgovarajuće biblioteke, s mahom orijentalnom knjigom, sve do prodora južnoslavenske, ali i literature na svjetskim jezicima od 18. st., pa nadalje, otvorene učenicima medrese, ali i široj javnosti, „da se njima koristi ko bude čitao i da iz njih

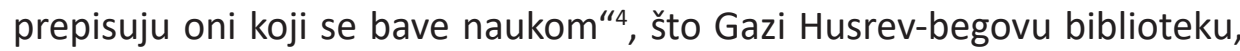
recimo, pozicionira kao prvu bosanskohercegovačku biblioteku otvorenu javnosti, istina, javnosti opismenjenoj u arapskom pismu i orijentalnim jezicima. Uz Gazi Husrev-begovu, kao reprezentativna pojavljuje se i Karađoz-begova biblioteka u Mostaru te samostalne biblioteke osnivane kao vakuf, poput one mostarskog državnika i pjesnika Derviš-paše Bajezidagića (osnovana 1593.), a za koju je vakif lično naložio i pravila rukovanja bibliotekom, potom Ćejvan Ćehajina biblioteka, također u Mostaru, ili, pak, one Abudullaha Kantamiri-zadea u Sarajevu. Punih 157 godina u Sarajevu je djelovala i samostalna Biblioteka Osman Šehdi Bjelopoljca, podignuta 1757., a čiji je fond nakon rušenja samostalne, namjenski izgrađene bibliotečke zgrade u dvorištu Careve džamije, stopljen s fondom Gazi Husrev-begove biblioteke. I izvan većih gradskih sredina, recimo u Gračanici, postojalo je nekoliko privatnih i javnih biblioteka, među kojima se ističe Halil-efendijina biblioteka, također prenesena u Gazi Husrev-begovu biblioteku 1939. godine, a u Travniku medresanska, i danas djelatna Elči Ibrahim-pašina biblioteka. I bez iscrpnog nabrajanja svih otkrivenih te valoriziranih bosanskohercegovačkih biblioteka orijentalnog tipa u Bosni i Hercegovini za vrijeme osmanske uprave, valja naglasiti da su bile uređene prema standardima sređivanja bibliotečkih fondova po uzoru na biblioteke Bliskog i Srednjeg Istoka, uz obavezno zaposlenog bibliotekara.

Jasno je, integriranjem Bosne $u$ islamsku civilizaciju, $i$ to posredstvom osmanske kulture, i ova podneblja posredno baštine dio utjecaja uspona islamske civilizacije u nauci, kulturi, umjetnosti i tehnologiji, što će se širiti i prema Istoku i prema Zapadu, krećući se upravo Putem svile, tragovi čega u Bosni jesu sačuvani i do danas, u bogatim rukopisnim zbirkama na arapskom, turskom i perzijskom jeziku unutar arhiva, biblioteka i muzeja te privatnih rukopisnih zbirki, ali i u arhitekturi, umjetnosti te u raznolikim formama tzv. nematerijalne kulture. $S$ islamsko-osmanskom kulturom u Bosni otvaraju se njezine veze te se produbljuju odnosi s istoč- 
njačkim kulturama, čime se Bosna kao poražena srednjovjekovna državna tvorevina otvara prema kosmopolitskom utjecaju brojnih kultura, obogaćujući svoju, u suštini marginalnu poziciju utjecajima iz velikih islamskih centara Bliskog i Srednjeg Istoka - rezultat čega jeste posredno učešće Bosne, kao krajnjeg ruba muslimanskog svijeta, u zlatnom dobu islamske nauke, umjetnosti i tehnologije.

S obzirom na to da su arapske vojske u sedmom i osmom stoljeću osvojile golema prostranstva - koja su se prostirala od Pirineja i Španjolske, preko sjeverne Afrike i cijelog Bliskog istoka pa sve do daleke Himalaje - stvarao se novi svjetski poredak. Bio je to svijet koji je ujedinjavao najbogatija, najuspješnija i najnaprednija područja rimskog Sredozemlja s dijelovima starog Perzijskog Carstva; nastala je nova supersila na tri kontinenta. Gradovi su se razvijali i cvjetali nakon što su napokon ponovo zavladali mir i stabilnost. [...] Bezizgledan početak u špilji u blizini Meke doveo je do nastanka nečeg što je nalikovalo na kozmopolitsku utopiju (idealno društvo u kojem žive ljudi iz različitih zemalja i kultura). To je označilo početak zlatnog doba za znanstvenike, trgovce i putnike. (Frankopan 2018: 42)

Pa ipak, uz biblioteke islamske provenijencije, u osmanskom periodu u Bosni i Hercegovini sve vrijeme istrajavaju i manastirske te samostanske, poglavito franjevačke biblioteke, posebno ojačane Ahdnamom - u ovom slučaju tzv. Fojničkom ahdnamom, nastalom po neposrednom osmanskom osvajanju Bosne 1463., kao dokumentu naloženom od strane sultana Mehmeda El-Fatiha (Mehmeda Osvajača) - kojim se u osmanskoj Bosni franjevačkom redu garantira vjerska sloboda, sloboda otvaranja samostanskih škola te biblioteka pri njima, sve u svrhu poučavanja puka te širenja pismenosti, pod uvjetom nesuprotstavljanja vladajućem režimu.

$S$ austrougarskom upravom u Bosni i Hercegovini za orijentalne biblioteke, a koje su posredstvom institucije vakufa de facto igrale ulogu državnih biblioteka, dolaze vremena nesređenosti, rasipanja te uopće nesnalaženja institucije vakufa u novim uvjetima te u novim proevropskim vremenima, što će rezultirati njihovim siromašenjem te slijevanjem mnogih manjih fondova u centralnu biblioteku orijentalnog tipa u Bosni i 
Hercegovini - u Gazi Husrev-begovu biblioteku, što je proces, barem kada su privatni orijentalni fondovi u pitanju, nedovršen čak ni do danas.

I pored razvojnih prijeloma, perioda zatišja u djelovanju, ali i perioda ponovne obnove fondova, smještajnih, kadrovskih i drugih potencijala, biblioteke orijentalnog tipa u Bosni i Hercegovini - kao jedna od najplodnijih izravnih posljedica doprinosa islamsko-osmanske kulture uopće bosanskohercegovačkoj knjižnoj kulturi - opstale su do danas, pojavljujući se najprije kao samostalne (javne) biblioteke orijentalnog tipa, poput Gazi Husrev-begove biblioteke u Sarajevu, potom kao biblioteke islamskih visokoškolskih ustanova, kao medresanske biblioteke, ali i kao orijentalne biblioteke u sastavu ili, pak, kao specijalne zbirke orijentalnog tipa unutar već postojećih biblioteka, $\mathrm{s}$ reprezentativnim primjerom odjela Islamice $\mathrm{u}$ Biblioteci Bošnjačkog instituta - Fondacije Adila Zulfikarpašića te Bošnjačke zajednice kulture „Preporod“.

Danas, najvrednije orijentalne zbirke u Bosni i Hercegovini u posjedu su nekolike ustanove, pojavljujući se unutar sva tri najdominantnija tipa baštinskih ustanova - arhiva, biblioteka i muzeja - te koje se, u skladu sa zahtjevima vremena, ali i vlastitim, nerijetko ograničenim mogućnostima, već preko dva desetljeća aktivno uključuju u projekte digitalizacije te digitalnog očuvanja orijentalne knjige. $U$ tome svakako prednjače (abecednim redoslijedom) Biblioteka Bošnjačkog instituta - Fondacije Adila Zulfikarpašića, Gazi Husrev-begova biblioteka u Sarajevu, Historijski arhiv Sarajevo, Biblioteka Orijentalnog instituta u Sarajevu te Nacionalna i univerzitetska biblioteka Bosne i Hercegovine, uz omanje digitalizacijske projekte unutar niza drugih baštinskih ustanova.

Digitalizacijski projekti Biblioteke Bošnjačkog instituta - Fondacije Adila Zulfikarpašića, tačnije orijentalne zbirke Islamica, započinju 2010. godine, rezultirajući s ukupno 743 digitalizirana rukopisna kodeksa, od kojih je, ilustracije radi, najstariji još iz 1342. godine, a koji obuhvataju 1125 djela iz oblasti teologije, etike, misticizma, filozofije, islamskog prava, logike, retorike, leksikografije, gramatike, historije, medicine, astronomije, astrologije i dr. Djela su bibliografski klasificirana te vidljiva unutar Kataloga arapskih, turskih, perzijskih i bosanskih rukopisa pohranjenih u Bošnjačkom institutu - Fondaciji Adila Zulfikarpašića (Zürich, 1997; Sarajevo-Zürich 2003). 
Najstarija, najrazvijenija te najistaknutija biblioteka orijentalnog tipa u Bosni i Hercegovini, pa čak i dalje, diljem Balkana i Evrope, Gazi Husrev-begova biblioteka u Sarajevu, koja je, nasreću, iz posljednjeg rata izašla s upotpunosti očuvanim vrijednim fondom, broji oko 10000 digitaliziranih rukopisnih kodeksa, od kojih je najstariji još iz 1131. godine, premašujući svojom starinom, recimo, i nemjerljivo češće isticanu Sarajevsku hagadu. Kao i u slučaju zbirke Islamica Bošnjačkog instituta - Fondacije Adila Zulfikarpašića, svi rukopisi bibliografski su opisani u Katalogu arapskih, turskih, perzijskih i bosanskih rukopisa pohranjenih u Gazi Husrev-begovoj biblioteci u Sarajevu. Danas su rukopisi trajno osigurani u reprezentativnoj, namjenski izgrađenoj zgradi Gazi Husrev-begove biblioteke u Sarajevu.

Orijentalnu zbirku Historijskog arhiva Sarajevo čini 1200 rukopisnih kodeksa s oko 2000 djela najrazličitijih sadržaja, a djela su, također, bibliografski opisana u Katalogu arapskih, turskih, perzijskih i bosanskih rukopisa pohranjenih u Historijskom arhivu Sarajevo.

Biblioteka Orijentalnog instituta u Sarajevu, uz Nacionalnu i univerzitetsku biblioteku Bosne i Hercegovine, najstradalnija je biblioteka u Bosni i Hercegovini, te nažalost, prva po gubicima fonda u ratu, kada su orijentalne biblioteke u pitanju. Ilustracije radi, Biblioteka Orijentalnog instituta u Sarajevu iz rata je izašla sa 108 rukopisnih kodeksa namjesto prijeratnih 5263, izgubivši, tako, svoje najstarije kodekse iz 11. st., dok se u ostacima rukopisne zbirke kao najstariji danas pronalaze kodeksi iz 15. st. Preživjeli rukopisi također su bibliografski dostupni unutar Kataloga arapskih, turskih, perzijskih i bosanskih rukopisa pohranjenih u Orijentalnom institutu u Sarajevu.

Nacionalna i univerzitetska biblioteka Bosne i Hercegovine jednako je tako u procesu digitalizacije orijentalne zbirke, koja broji oko 1000 kodeksa, bibliografski popisanih unutar Kataloga arapskih, turskih, perzijskih i bosanskih rukopisa pohranjenih u Nacionalnoj i univerzitetskoj biblioteci Bosne i Hercegovine.

Sve spomenute bosanskohercegovačke digitalizacijske projekte vezane uz mrežnu vidljivost te digitalno očuvanje orijentalnih kodeksa, ali i arhivske građe povezuje niz sličnosti te srodnih institucijskih praksi: 1) iznimna vrijednost digitaliziranih kodeksa i arhivske građe; 2) osoblje još 
uvijek mahom obrazovano u "tradicionalnim“ disciplinama - orijentalna filologija i historija - bez danas nužnih informacijsko-komunikacijskih znanja i vještina, što za baštinske ustanove kao posljedicu ima sve manje isplativo posuđivanje ekspertskog znanja izvana; 3) nedostatak nacionalnih smjernica te interoperabilnosti u digitalizaciji rukopisne građe; 4) nedostatak odgovarajuće opreme, te posljedično oslanjanje na vaninstitucionalnu saradnju; 5) kao i još uvijek nedovoljno razvijeni modeli uzajamne digitalizacije između zainteresiranih ustanova.

Stoga se, uočavajući institucijske prakse razmatranih biblioteka te srodnih baštinskih ustanova, izdvajaju i preporuke vezane uz moguće unapređenje digitalizacijskih projekta orijentalnih rukopisnih kodeksa te ostale građe u $\mathrm{BiH}: 1$ ) snažnije umrežavanje ustanova koje baštine orijentalno naslijeđe u BiH s ciljem udruženih, uzajamnih projekata; 2 ) udruženo apliciranje na projekte digitalnog očuvanja orijentalne građe u zemlji i u inozemstvu; 3) udruženo stručno usavršavanje te cjeloživotno obrazovanje zaposlenika u baštinskim ustanovama koje skrbe o orijentalnim zbirkama; 4) udružene, jedinstvene mogućnosti rješavanja tehničkih pitanja digitalizacije, sistema za online katalogizaciju, kao i sistema za upravljanje pohranjenim sadržajima; 4) jačanje aktivnosti na mrežnoj vidljivosti digitalizirane građe; 5) snažniji angažman na projektima dugotrajnog očuvanja digitalizirane građe.

Čak i u relativno kratkom pregledu prošlosti, sadašnjosti te budućnosti knjižne kulture u Bosni i Hercegovini neposredno prije, tokom, ali sad već i stoljećima nakon osmanske uprave u Bosni, utjecaji islamsko-osmanske kulture nemjerljivi su u svojim direktnim i posrednim učincima, trajući sasvim očigledno u brojnim aspektima i danas. Bosanskohercegovačke ustanove baštine i danas se skrbe o rukopisnim kodeksima dopremljenim iz velikih islamskih centara Bliskog i Srednjeg Istoka u Bosnu - na sami rub islamskog svijeta ka kršćanskoj Evropi - kao i o onim rukopisima koji su po uzoru na orijentalne nastajali u Bosni, istina, alatima i tehnologijama koje su primjerene novom vremenu i okruženju, poput digitalizacije, ali i uz stalni osvrt na početna ishodišta, jer „da bismo razumjeli svijet sadašnjosti i budućnosti, moramo razumjeti svijet prošlosti. A da bismo to učinili, najbolje je krenuti od početka. Igrom slučaja, to znači početi upravo s Putovima svile" (Frankopan 2018: 11). 


\section{Izvori i literatura}

Bašeskija, Mula Mustafa. Ljetopis: (1746-1804). Sarajevo: Veselin Masleša, 1968.

Čelić, Džemal. „Tokovi pisane riječi u Bosni i Hercegovini“. Alija Isaković i Milosav Popadić (ur.). Pisana riječ u Bosni i Hercegovini: od najstarijih vremena do 1918. godine. Sarajevo: Veselin Masleša, 1982. 5-34.

Čeliković, Senad. Islamske biblioteke u Bosni i Hercegovini 1878-2010. Tuzla: JU Specijalna biblioteka „Behram-beg“, 2014.

Dizdar, Majo. Sarajevski vakifi i njihovi vakufi: 1462.-2001. Sarajevo: autor, 2010.

Frankopan, Peter. Putovi svile: nova povijest svijeta. Zagreb: Školska knjiga, 2018.

Grozdanić, Sulejman. „Pisana riječ na orijentalnim jezicima i alhmijado“. Alija Isaković i Milosav Popadić (ur.). Pisana riječ u Bosni i Hercegovini: od najstarijih vremena do 1918. godine. Sarajevo: Veselin Masleša, 1982. 85-140.

Hadžiosmanović, Lamija. „Biblioteke“. Alija Isaković i Milosav Popadić (ur.). Pisana riječ u Bosni i Hercegovini: od najstarijih vremena do 1918. godine. Sarajevo: Veselin Masleša, 1982. 285-295.

Kaleši, Hasan. „Prve orijentalne biblioteke u jugoslovenskim zemljama“. Bibliotekar XIII, 4 (1961): 280.

Kreševljaković, Hamdija. Esnafi i obrti u starom Sarajevu. Sarajevo: Narodna prosvjeta, 1958.

Kuna, Herta. „Srednjovjekovna bosansko-hercegovačka književnost“. Alija Isaković i Milosav Popadić (ur.). Pisana riječ u Bosni i Hercegovini: od najstarijih vremena do 1918. godine. Sarajevo: Veselin Masleša, 1982. 49-84.

Lavić, Osman. Biblioteke u Bosni za vrijeme osmanske uprave: magistarski rad. Sarajevo: autor, 2013.

Mujezinović, Mehmed. Islamska epigrafika Bosne i Hercegovine. Knj. I, II, III. Sarajevo: Sarajevo-Publishing, 1998. 


\title{
Lejla Kodrić Zaimović
}

\section{ARABIC, TURKISH AND PERSIAN MANUSCRIPTS IN BOSNIA AND HERZEGOVINA AND THE SILK ROAD: FROM THE BEGINNINGS OF THE INSTITUTIONALIZATION TO THE HERITAGE INSTITUTIONS CONTEMPORARY DIGITAL PRACTICES}

\begin{abstract}
Summary
Bosnian-Herzegovinian contemporary heritage institutions store many valuable manuscripts originating from Middle East countries, among wich there are manuscripts dated from 12th century onwards. The manuscripts of Arabic, Turkish and Persian origin, later enriched with Bosniac authors transcriptions or autographs, even today represent the most valuable collections of Bosnian-Herzegovinian heritage institutions. The Arabic, Turkish and Persian manuscripts were surely arriving in Bosnia along the Silk Road. Over several decades there has been activity of cataloguing Arabic, Turkish, Persian and Bosnian manuscripts in Bosnian-Herzegovinian heritage institutions, some of wich were founded in the Ottoman Bosnia, like the Gazi Husrev-bey's Library in Sarajevo, but still functioning today. Based on the available literature and published Catalogues of Arabic, Turkish, Persian and Bosnian manuscripts of the prominent Bosnian-Herzegovinian heritage institutions, the paper reconstructs the ways of islamic provenance book arrival in Bosnia and the connection with the Silk Road as a key cultural and communication hub, but also influences of different Middle East and, indirectly, Far East cultures on the past and present of Bosnian-Herzegovinian heritage.
\end{abstract}

Key words: Arabic, Turkish and Persian manuscripts, Bosnia and Herzegovina, heritage institutions, the Silk Road, Catalogues of Arabic, Turkish, Persian and Bosnian manuscripts, digitization. 